Tér és Társadalom 24. évf. 2010/1. 83-101. p.

Tér és Társadalom

XXIV. évf. 2010 1: 83-117

\title{
ÖNKORMÁNYZATISÁG
}

\section{AZ „ÖNKORMÁNYZATI RISK MAPPING” AVAGY A „CAMELS TÍPUSÚ” ELEMZÉSEN ALAPULÓ ÖNKORMÁNYZATI RATING ÉS MONITORING RENDSZER}

\author{
(The "Local Governments Risk Mapping" Method or the Local \\ Governments Rating and Monitoring System Based \\ on "CAMELS Analysing" Method)
}

\section{GÁL ERZSÉBET}

Kulcsszavak:

mutatószám rendszer camels önkormányzati gazdálkodás pénzügyi kockázat elemzés

A helyi önkormányzatok gazdálkodása során keletkezö pénzügyi kockázatok idöben és helyesen történö azonosítása valamennyi velük kapcsolatban alló gazdasági szereplö érdeke. A tanulmány javaslatot fogalmaz meg egy pénzügyi mutatószámrendszer kialakítására, mely segítséget nyújthat a kereskedelmi bankok hiteldöntéseiben, az Állami Számvevöszék ellenörzési munkájában, valamint a helyhatóságok controlling rendszerének fejlesztésében.

\section{Bevezetö}

„A magyar önkormányzati rendszer kialakulását a fogantatás és a szuiletés pillanatai (in situe nascendi) jelentősen meghatározták." (Vigvári 2008, 141) A jelenlegi magyar önkormányzati rendszer kiindulópontja a 1971-ben született tanács-törvény, illetve az annak 1986-ban történt újraszabályozása. Az 1986-os törvény teremtette meg a máig is élő és mủködỏ egységes (akkor még tanácsi) pénzalapot, mely a fejlesztési és a müködési költségvetés átjárhatóságán alapult. Ez a szabad átjárhatóság járult hozzá többek között az önkormányzatok költségvetési korlátjának (Kornai et al. 2004a; 2004b) felpuhításához. A finanszírozás tekintetében a helyben képződött bevételeknek szánták a döntő szerepet, míg a feladatellátás terén egy deklarált minimumot határoztak meg. 1989-tól bevezették a forrásorientált rendszert, mely a pénzügyi architektúra ${ }^{1}$ más jellemzói mellett, nagyfokú pénzügyi önállságot biztosított a helyhatóságoknak.

Hazánkban a helyi önkormányzatoknak, mint az államháztartás alrendszereinek alapvetỏ célja a feladatellátás és az intézménymüködtetés. A kötelező feladatokat melyek mellett lehetnek önként vállaltak is - a központi költségvetés decentralizáció 
útján delegálja az alsóbb szintü kormányzatoknak. A kötelezö feladatok ellátásához az Alkotmány és az Ötv. alapján arányos mértékben ${ }^{2}$ a központi költségvetés hozzájárul, míg az önként vállalt feladatokat a helyi önkormányzatoknak helyi szinten kell kigazdálkodniuk. Az önkormányzatok a feladat-ellátási kötelezettségekkel, az intézménymüködtetéssel és beruházási tevékenységeikkel összefüggésben a közszektor szereplöi mellett a vállalkozói szektorral is kapcsolatba kerülnek.

A decentralizáció mértéke meghatározó jelentőséggel bír a helyi önkormányzatok autonómiája szempontjából, míg a helyi önkormányzati szintekhez rendelt feladatok és jogkörök mennyiségi és minöségi jellemzői meghatározzák az adott ország helyi önkormányzatának önállóságát és mozgásterét. Ezek között a jellemzők között megkülönböztetett figyelmet érdemel az intézménymúködtetés, a feladatellátás és hatáskör gyakorlás pénzuigyi alapjainak, finanszírozási kérdéseinek problémája. Az alsóbb szintủ kormányzatok feladataikat az általuk kezelt pénzalapokból finanszírozzák, mely pénzalapok müködtetési szabály és feltételrendszerét, a szereplök költségvetési korlátjának keménységét (Vigvári 2005), a tökepiaci kapcsolataik szabályrendszerét pénzügyi architektúrának nevezzük. Az önkormányzati feladatellátás alapvető gazdasági alapját képezi az önkormányzati vagyon. A feladatellátás fontos szervezeti egységét jelentik az önkormányzati tulajdonú gazdasági társaságok. Ezek részei az önkormányzati vagyonnak, de emellett a költségvetésen kívüli feladatellátás legfontosabb szervezeti keretei.

A helyi önkormányzati rendszer pénzügyi architektúrájában kiemelt szerepet kap az egyéb kormányzati pénzalapok igénybevételének szabály és eszközrendszere. A kötelezően elöírt és az önkormányzatokhoz delegált feladatokhoz történö állami hozzájárulások és támogatások rendszerét nagymértékben meghatározzák a hozzájárulások allokációjának mechanizmusa, az alkalmazott instrumentumok típusai ${ }^{3}$ és a pénzellatás rendje. Ez a kapcsolat kölcsönös, hiszen nem csupán az állam ad át forrásokat transzferek, megosztott adók formájában a helyi önkormányzatoknak, hanem a helyi önkormányzatokat is fizetési kötelezettség terheli az államháztartás egyes alrendszerei felé.

$\mathrm{Az}$ önkormányzatok egységes pénzügyi alapja és maga a pénzügyi architektúra létrejöttének és kialakitásának célja, hogy a helyi önkormányzatokat érdekeltté tegye saját bevételek szerzésében, hiszen a központi költségvetés által juttatott források csak részben finanszírozzák a kiadási szükségleteiket. Azok az önkormányzatok, amelyek - adott gazdasági körülmények között - magasabb saját bevétel arányt tudnak biztosítani, növelni tudják függetlenségüket a központi költségvetéstöl, de $a$ képzeletbeli köldökzsinór elszakítására sem rövid, sem hosszú távon nincs mód. Az önállóság növelése során szem előtt kell tartani a kiegyensúlyozott költségvetés elsődleges fontosságát!

A rendszer elaprózottsága miatt a szektorban nagyszámú, de igen különböző súlyú szereplö van jelen (1. táblázat). Ezeknek a szereplöknek az elhelyezkedése regionálisan is különbözö. 
Gál Erzsébet : Az „Önkormányzati Risk Mapping”

avagy a „CAMELS típusú" elemzésen alapuló önkormányzati rating és monitoring rendszer.

Tér és Társadalom 24. évf. 2010/1. 83-101. p.

TÉT XXIV. évf. 2010 — 1

Önkormányzatiság

85

\section{TÁBLÁZAT}

A helyi önkormányzatok közigazgatási rang szerinti megoszlása

(Distribution of Local Governments)

\begin{tabular}{cccccc}
\hline $\begin{array}{c}\text { Föváros/ } \\
\text { Megye }\end{array}$ & $\begin{array}{c}\text { Fövárosi } \\
\text { kerület }\end{array}$ & $\begin{array}{c}\text { Megyei } \\
\text { jogú város }\end{array}$ & Város & $\begin{array}{c}\text { Nagyközség, } \\
\text { község }\end{array}$ & Összesen \\
\hline $20 \mathrm{db}$ & $23 \mathrm{db}$ & $23 \mathrm{db}$ & $304 \mathrm{db}$ & $2824 \mathrm{db}$ & $3194 \mathrm{db}$ \\
\hline
\end{tabular}

Forrás: PM adatok alapján saját szerkesztés.

Az önkormányzatok viselkedésüket tekintve átmenetet képviselnek a gazdaságban a költségvetési logika alapján és a piaci logika alapján müködö szereplök között. Ez a kettősség nem csak a nagyfokú alkotmányos szabadságukban, de költségvetési kapcsolatrendszerükben, számviteli információs rendszerükben, tökepiaci kapcsolataikban, valamint a feladatellátás jelentős költségvetésen kívüli súlyában is tetten érhetö. Ebböl a kapcsolatrendszerböl adódóan a vállalkozói szektorban alkalmazott elemzési és ellenőrzési módszerek, kellö körültekintéssel alkalmazhatóak lehetnek az önkormányzatok esetében is.

Ilyen elemzési, rating és monitoring módszer a kereskedelmi bankok müködését elemzỏ és ellenőrzó CAMELS mutatószám rendszer. A tanulmány a továbbiakban arra tesz kísérletet, hogy javaslatot tegyen a modell önkormányzatokra történö alkalmazására. A modell elsősorban a kereskedelmi bankok hiteldöntéseit támogató kockázat mérő és elörejelző rendszer körvonalait igyekszik meghatározni. A modell kidolgozásának jelenlegi fázisában javaslatot fogalmaz meg, és ezzel együtt még nem ígér lezárt rendszert!

\section{Elemzési kérdések és a megválaszoláshoz használható módszerek}

A magán és a közszektor közötti éles határvonal fokozatos elmosódása több területen is megfigyelhető. Érzékelhető ez egyrészről a közszektort érintő reformok hatására kialakult feladattelepítési technikáknak a közszektorban történő térhódításában (Zupkó 2002). Erre utal továbbá a vállalkozások esetében és a közszektorban használt eltérö számviteli elvek közelítésének egyre sürgetöbb igénye is (Kassó 2006). A fentieket mintegy kiegészíti a transzparencia követelményének egyre markánsabb jelenléte mind a közszektorban, mind a magánszektorban.

A két szektorban feltárható kockázatok azonosításának és mérésének azonos bázisra történő helyezését könnyíti meg az elemzési módszerek interdiszciplináris jellege. Ez a jellemvonás teszi lehetővé, hogy a két szektorban kitapintható eltérő célfüggvények ellenére a célok elérését akadályozó kockázatok mindkét területen azonos módszerekkel mérhetők legyenek.

Az elemzési eljárások közül a matematikai-statisztikai módszereknek ${ }^{4}$ a területi kutatásokban történő alkalmazása az 1900-as évek közepétől vált egyre elterjedtebbé. A múlt század végére pedig a különböző informatikai fejlesztéseknek köszönhetően a települési és területi vizsgálatokban is lehetővé vált a különböző matematikai és 
Tér és Társadalom 24. évf. 2010/1. 83-101. p.

statisztikai eljárások alkalmazása. A területi mennyiségi vizsgálatok esetében a fő cél az egyes adattömegekben megtalálható információk sủrítése, majd a kinyerhetó és értelmezhető mutatók segítségével az aktuálisan vizsgált jelenség vagy folyamat elemzése (Lengyel 1999). A fenti statisztikai módszerek a területi kutatások mellett a marketing kutatások fejlődését is elöre mozdították, azoknak az analitikus marketingrendszerben történő alkalmazásával (Kotler 1991).

Az elemzési módszerek interdiszciplináris jellegét támasztja alá a DuPont mutatószámrendszernek az üzleti szektorban történő széles körü elterjedése is ${ }^{5}$. A mutatószámrendszer az összes befektetett tőke megtérülésének vizsgálatát helyezi a középpontba. Ez az elemzési módszer egy vegyipari óriáscég saját fejlesztésében jött létre, majd vált az üzleti életben - többek között a bankszektorban is - széles körben elismert és elterjedt elemzési eszközzé.

Hasonló elemző és értékelő módszer a kiegyensúlyozott mutatószámrendszer, a Balanced ScoreCard (továbbiakban: BSC) is ${ }^{6}$. A BSC alkalmazása a vállalkozások kiegyensúlyozott, négy nézőpont szerinti fejlődését segíti elö, amely az adott feltételek között a maximális nyereség realizálásának feltétele (Kaplan-Norton 1998). A teljesség igénye nélkül megemlíthetö továbbá az 1990-es években a tanácsadás területén ismertté vált Boston Consulting Group növekedési / részesedési mátrixa (BCG mátrix), mely a különböző portfólió elemzések során nyújt segítséget az elemzö számára (Kotler 1991).

A tanulmány szempontjából releváns rating és monitoring rendszereknek (mint elemzési módszernek) gyakorlati alkalmazására a kereskedelmi bankokat vizsgálva több esetben is láthatunk példát. Az ügyfeleik minősítésekor gyakran alkalmazzák az $5 C$ módszert, amely öt tényezỏ angol elnevezésének a rövidítése: a Capital (saját erỏ nagysága), Capacity (a vállalat eszközeinek értéke), Collateral (fedezetek), Conditions (piaci, konjunkturális és múszaki feltételek) és Characters (a menedzsment tulajdonságai). A bankok ügyfélminősítỏ rendszerei ezeket a tényezőket mérik pontozással. A pontok összeadásával adódik a minősítés eredménye. A minősítés során nem a pontok abszolút értéke, hanem azok értékeinek változása, illetve valamilyen más (azonos módon minősített) értéktöl (más szereplő, piaci átlag, benchmark) való eltérése az érdekes.

A fentiekhez hasonló pontozáson alapuló elemzö és monitoring rendszer a CAMELS módszer (Gál 2009b). A CAMELS elemzés eredetileg felügyeleti vizsgálati módszerként került kialakításra a bankszektorban, majd vált fokozatosan egyre szélesebb körben ismertté. Ennek az elemző és értékelő rendszernek rendkívül nagy előnye, hogy rugalmas, vagyis az elemzést készíttető igényeinek és a vizsgált pénzintézet adottságainak megfelelően alakítható. A CAMELS modell elsösorban a vizsgált pénzintézet kockázati területeinek feltárására helyezi a hangsúlyt, valamint az adott területen feltárt kockázatoknak az idöben történö észlelésére. Az „Önkormányzati Risk Mapping" ennek a modellnek az önkormányzati szektorra történő átültetésére tesz kísérletet. 
Tér és Társadalom 24. évf. 2010/1. 83-101. p.

TÉT XXIV. évf. 2010 - 1

Önkormányzatiság

87

\section{A megvalósítás lépései}

A „Önkormányzati Risk Mapping” egy olyan értékelési rendszer létrehozására tesz javaslatot, amelynek segítségével meghatározhatók az önkormányzati gazdálkodás pénzügyi kiegyensúlyozottsága, szabályszerủsége és célszerüsége szempontjából kritikus kockázati elemek (tényezók). Ezekhez az elemekhez megfelelö menynyiségi és/vagy minőségi indikátorokat (tényezóértékelési szempontok) szuikséges rendelni. Az indikátorok - különböző objektív és/vagy szubjektív alapon számítható módszerekkel - mérhetővé, valamint az egyes - a modell-tesztelések során meghatározásra kerülő - küszöbértékeknek megfelelően a kritikus kockázati elemek osztályozhatóvá válnak (osztályozás). Az egyes kockázat-csoportokhoz megfeleló súlyokat rendelve (súlyozás) lehetővé válik a különböző önkormányzatok kockázatossági szempontból történö összehasonlítása is. Az így nyert értékek számításához szükséges paraméterek folyamatos (évente kétszer történő) mérése segítségével kialakítható egy monitoring rendszer is (monitorizálás).

A monitoring rendszer lehetővé teszi a különböző kockázati elemek (tényezők) értékében bekövetkező hirtelen változások észlelését. Gyakorlatilag erre alkalmazzák a kereskedelmi bankok is a negyedéves monitorizálás rendszerét ( $G a ́ l$ 2009a). E változások iránya és mértéke olyan jelzésként funkcionál, melynek - megfelelöen kialakított mutatószámok és tényezők esetén - segítségével a rendszer kuilönböző veszélyhelyzetek korai elörejelzésére (early warning system) is alkalmas lehet. A fentiek mellett az „Önkormányzati Risk Mapping” alátámaszthatja a kereskedelmi bankok önkormányzati hiteldöntéseit, hatékony segítséget nyújthat az ÁSZ külső ellenörzó munkájának racionalizálásában, valamint a helyhatóságok stratégiai szemléletmódjának fejlesztésében is.

A módszer alkalmazásának alapfeltétele egy viszonylag könnyen, minden önkormányzatra azonos módszerrel számítható pénziugyi mutatószámrendszer kialakítása. Az „Önkormányzati Risk Mapping” piacképes modelljének kialakítása több, egymást követő lépések sorozataként jöhet létre:

\section{1) A tényezók azonosítása az önkormányzatok kockázati térképe segítségével.}

Az önkormányzatok kockázataival, azok feltárásával, összegzésével és azok egyes területeinek elemzésével több helyen is foglalkozik a szakirodalom (Hegedüs 2004; ÁSZ FEMI 2007; Hegedüs-Tönkö 2007; Varga 2007; Homolya-Szigel 2008; Vigvári 2009). Az elemzett területeken definiált kockázatok az önkormányzati rendszer kialakulásához köthetők, és a különböző - a rendszer valamilyen szintủ reformját elősegítő - intézkedések ellenére továbbra is megtalálhatóak.

A továbbiakban a kockázatok definiálása és meghatározása szempontjából a kockázati térképet emeljük ki, és kísérletet teszünk annak bővítésére. A kockázati térképnek egy sajátos megközelítését négy nagy elemre bontva és az ,elvárható kontroll'-t ezen kockázati területekhez hozzá rendelve mutatja be Vigvári Közpénzügyeink címủ 
könyvében (Vigvári 2005). A kockázati térkép ebben a megközelítésben a feladatellátásra, a pénzügyi helyzetre, a vagyongazdálkodásra és a településpolitikára fókuszál, mint egy-egy kiemelendő területre.

A kockázati térkép ábrázolására egy koordináta rendszerben is lehetőség nyílik ${ }^{7}$. Ennek a levezetését mutatja be a tanulmány következő része.

\section{A kockázati térkép „y” tengelyének értelmezése}

Az önkormányzatok müködésével kapcsolatosan csak a múlt- és a jelenbeli helyzet kockázatait lehet kimutatni. Az önkormányzatokat érintö törvények rendszerint évente változnak, az elörejelzések megbizhatóságának foka alacsony. Az idődimenziónak a kockázatkezelés folyamatába történő bekapcsolására nincs mód, ezért a kockázatok évenkénti értékelése szükséges. Ehhez az alapvető kockázati elemek elkülönítésére van szükség, melyre 17 alapvetö kockázatot jelölünk meg ${ }^{8}$ :

- Vagyonfelés kockázata;

- Információgazdálkodási rendszer hiányosságainak kockázata;

- A vezetés kompetencia hiánya;

- Mérlegen kívüli kötelezettségvállalások kockázata (Off-balance sheet item-ek);

- Túlzott eladósodottság kockázata;

- Politikai kockázat;

- Pénzintézetek és önkormányzatok közös moral hazardja;

- Megalapozatlan beruházások;

- Látens csőd;

- Abszorpciós képesség hiánya;

- Makro kockázatok;

- Likviditás hiány;

- Indokolatlan gazdaságfejlesztések;

- Túl sok önként vállalt feladat;

- Kiegyensúlyozatlan költségvetés;

- Költségvetésen kívüli kockázatok (Off-budget kockázatok);

- Kötelező feladatok alulfinanszírozása.

A fenti kockázatok mérhetősége szempontjából az első lépés annak a vizsgálata, hogy az adott kockázatok milyen ok-okozati összefüggésben vannak egymással, vagyis hogyan képesek hatni egymásra, a puszta jelenlét mellett. Ez a hatás lehet egymást erösítö, de semleges is ${ }^{9}$. Az egyes tényezők közötti ok-okozati összefüggés vizsgálata során három kategóriát használhatunk: 0,1 és 2 . Az értékelésnél vízszintesen 2 pontot kap egy kockázat, amennyiben az alternatív kockázat (függöleges oszlop) kiválthatja azt (okozat), illetve 1 pontot, amennyiben az alternatív kockázat kialakulását ö idézi elő $(o k)$. Azokban az esetekben, ahol nem mutatható ki egyértelmú ok-okozati kapcsolat az egyes tényezők között, $O$ pontot adunk. (A vizsgálat célja annak a meghatározása, hogy az adott kockázat mértéke - a kölcsönhatásokat is figyelembe véve-mekkora.) 
A jelentőség megállapításánál a következỏ elvet követtük:

- a kockázat jelentösége kicsi, amennyiben a legtöbb pontszámot kapó kockázat pontértékének egyharmadát nem éri el;

- a kockázat jelentősége közepes, amennyiben a legtöbb pontszámot kapó kockázat pontértékének egyharmadát meghaladja, de kisebb, mint annak kétharmada;

- a kockázat jelentösége nagy, amennyiben a legtöbb pontszámot kapó kockázat pontértékének kétharmadát meghaladja.

A vizsgálat elvégzése után a kis jelentöségü kategóriába kerültek: az információgazdálkodási rendszer hiányosságai, az abszorpciós képesség hiánya, a makro kockázat, valamint a kötelezö feladatok alulfinanszírozása. A közepes jelentöségü kategóriába kerïltek: a vezetés kompetencia hiánya, az off balance sheet kockázatok, a pénzintézetek és önkormányzatok moral hazardja, a megalapozatlan beruházások, a látens csöd, a likviditási hiány, az indokolatlan gazdaságfejlesztés, a túl sok önként vállalt feladat, a politikai kockázat és az off budget kockázatok. Végül a legjelentösebb kockázatot hordozó tényezök: a vagyonfelélés, a túlzott eladósodottság, és a kiegyensúlyozatlan költségvetés.

\section{A kockázati térkép „x” tengelyének értelmezése}

A kockázatok egymáshoz viszonyított mértéke nem mutatja be pontosan az adott önkormányzatok helyzetét, hiszen az egyes kockázatok nem azonos valószínüséggel következnek be, egymáshoz képest sem, föként, ha a szektor szintủ sajátosságokat is figyelembe vesszük. A kockázatok „észlelt” valószínüségének (x tengely) értékelésekor a szektorról készített elemzéseken, jelentéseken kívül különböző becslések is rendelkezésre állnak. A valószínüségek adott idöpillanatban észlelt valószínüségek, melyek dinamikusan változhatnak, ahogyan a kockázatok mértéke is dinamikusan változik. Megítélésük és besorolásuk tehát az adott kockázat részletes vizsgálata alapján lehetséges. A szektorról készült elméleti és empirikus vizsgálatok eredményeit felhasználva értelmezhetők a valószínủségek. (Amennyiben nem a szektorról készítjük az elemzést, itt nyílik lehetőség az adott önkormányzat sajátosságainak, szektor átlagtól vagy benchmarktól való eltérésének érzékeltetésére.)

$\mathrm{Az}$, ,X" tengely értelmezését Gál (2009b) végezte el részletesen. Az elemzés alapján az egyes kockázatokhoz észlelet valószínüségek rendelhetők hozzá, melyben a valószínüségek kicsi, közepes és nagy értékeket kaphatnak. Az esetleges alacsony valószínủség vagy jelentőség ellenére az értékelés során minden kockázatot figyelembe kell venni, mert annak dinamikája miatt a következő években változhat a megítélésük.

Ezt az ábrázolási módot felhasználva készítettük el az önkormányzati rendszer aktuális kockázati térképét ( 1 . ábra) jelölve az egyes kockázati tényezők esetében a lehetséges elmozdulási irányokat is. Erre azért van szükség, mert ahogyan az önkormányzatok mủködését körülvevő gazdasági környezet sem állandó, úgy dinamikus változásra képesek az egyes kockázati elemek is. 
Gál Erzsébet : Az „Önkormányzati Risk Mapping”

avagy a „CAMELS típusú" elemzésen alapuló önkormányzati rating és monitoring rendszer.

Tér és Társadalom 24. évf. 2010/1. 83-101. p.

1. ÁBRA

Az önkormányzatok kockázati térképe

(Risk Map of Local Governments)

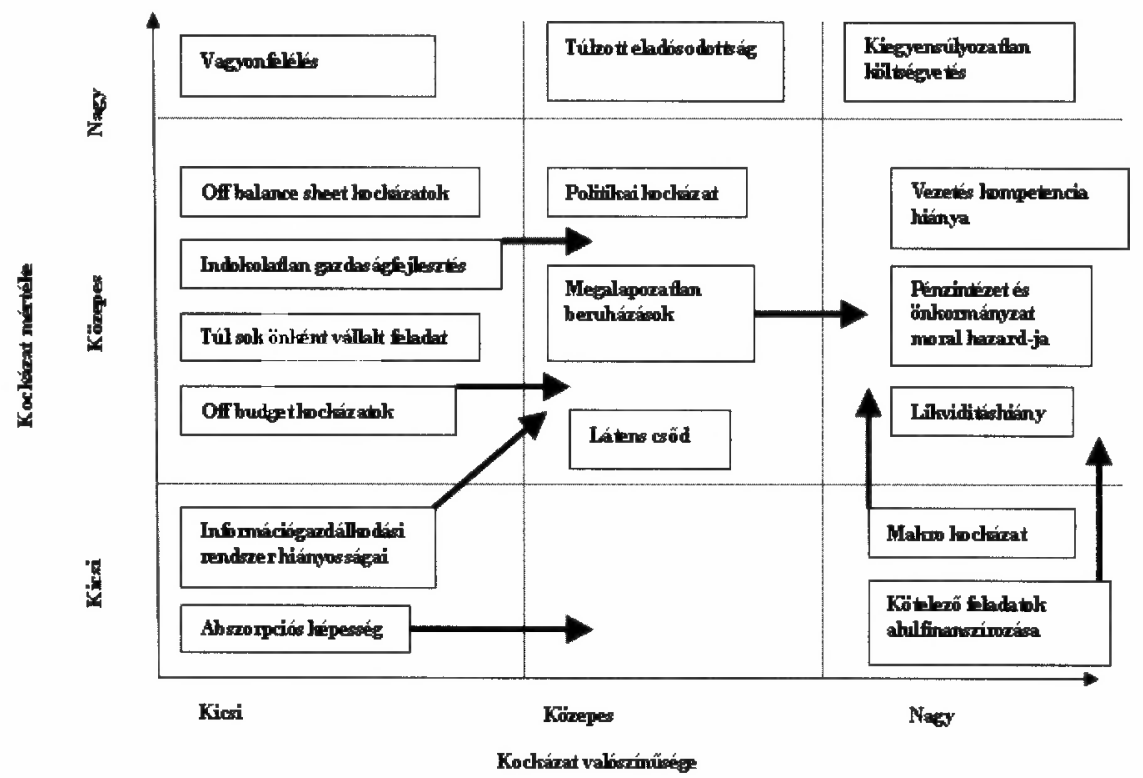

Forrás: Saját szerkesztés.

A fenti ábrázolás az önkormányzati rendszer egészére vonatkozó benchmark lehet csak, ami nem feltétlenül esik egybe a különböző önkormányzati szegmensek esetében érvényes valószínűséggel, hiszen más-más súllyal esik latba például az offbudget kockázat egy község és egy megyei jogú város esetében. Ennek ellenére a fenti kockázatoknak a kockázati térképen történö azonosítása elvezet az „Önkormányzati Risk Mapping" tényezöinek levezetéséhez. Feltételezve, hogy a fenti kockázati elemekkel jól leírhatók a rendszer kockázatai.

Vigvári 2002-ben vázolt elképzelésében hat tényezőt emelt be a vizsgálandó területek közé, melyek a Költségvetés szerkezete, Bevételi kapacitás, Feladatellátás, Pénzügyi kapacitás, Eladósodottság és Likviditás (Vigvári 2002a). A kockázati térképen (1. ábra) vázolt kockázatok elhelyezkedését és a lehetséges elmozdulási irányokat is figyelembe véve - a kockázatok 2002 óta bekövetkezett dinamikáját is mérlegelve -, hat tényező segítségével leírható az önkormányzatokat körülvevő önkormányzati kockázati erőtér (2.ábra). A kockázatok ezen hat tényezỏ között oszthatóak fel.

Az elemzést készítő számára az „Önkormányzati Risk Mapping” lehetőséget ad arra, hogy a tényezők súlyozásával, - mely a végső értékelést adja - érzékeltesse az adott önkormányzat esetében érvényesülö relevanciát a kockázatok tekintetében.

A modellalkotás jelenlegi fázisában a második feladat a tényezők meghatározását követően, azok pontos definiálása, melyet Gál (2009b) végzett el részletesen. 
Gál Erzsébet : Az „Önkormányzati Risk Mapping”

avagy a „CAMELS típusú" elemzésen alapuló önkormányzati rating és monitoring rendszer.

Tér és Társadalom 24. évf. 2010/1. 83-101. p.

TÉT XXIV. évf. 2010 ॠ 1

Önkormányzatiság

91

2. ÁBRA

A Risk Mapping tényezöi - az önkormányzati kockázati erötér

(Factors of Risk Mapping)

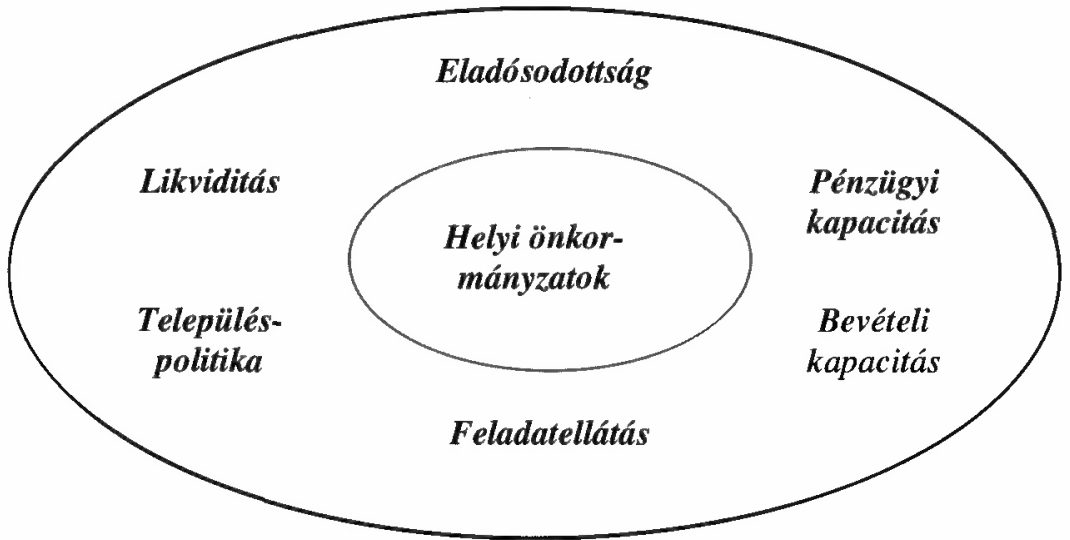

Forrás: Saját szerkesztés.

2) A tényezö-értékelési szempontok, indikátorok meghatározása.

A tényezö-értékelési szempontok azt a célt szolgálják, hogy segítségüikkel leírhatóvá, jellemezhetővé váljanak az egyes kockázati elemek, vagyis maguk a tényezők. A tényezők értékelése során néhány értékelési szempont több tényezőnél is előfordulhat, ami hangsúlyozza a tényezök közötti összefüggés fontosságát. Az értékelési szempontok sorrendje nem jelent fontossági sorrendet (Economic Research 1999). Az elemzés során törekedni kell arra, hogy a tényezö-értékelési szempontok minél szélesebb körben legyenek képesek tükrözni a vizsgált önkormányzat kockázati profilját és komplexitását. Ezek természetesen önkormányzat típusonként, de akár adott szegmensen belül is eltérőek lehetnek. Az elemzést készítő feladata ezeknek a sajátosságoknak a feltérképezése, és a helyes és elégséges elemzési módszereknek az alkalmazása.

A tényezö-értékelési szempontok segítséget jelentenek a kockázat mérésében. A kockázatoknak azonban csak egy bizonyos része fejezhetỏ ki objektív mutatószámok segítségével. Az információk másik része a költségvetési beszámoló rendszerből nem olvasható ki. Ezeknek a szubjektív szempontoknak a mérése kérdőívek segítségével valósulhat meg. A kérdőívek lekérdezésére a modell vizsgálati szakaszában a személyes interjúk alatt van lehetöség. A továbbiakban ennek a logikának a segítségével osztottuk a tényezö-értékelési szempontokat objektív és szubjektív elemekre. 
Tér és Társadalom 24. évf. 2010/1. 83-101. p.

\section{Eladósodottság}

Objektiv szempontok

- Az adósságállomány és a GFS egyenleg alakulása, tendenciája;

- A felvett hitelek típusai, futamideje, a törlesztés mértéke. A kibocsátott kötvények összege, törlesztési struktúrája;

- A hitelfelvételi korlát betartásának vizsgálata;

- A felajánlott fedezetek alakulása. Itt vizsgálni kell a vagyongazdálkodást, a törzsvagyon és a forgalomképes vagyon arányának alakulását, a terhelhetô vagyon szerkezetét és terheltségét;

- Az esetleges PPP beruházások eladósodottságot módosító hatásának számszerüsítése;

- Az önkormányzatok által nyújtott kezességek és vállalt garanciák öszszege;

- A korábbi években beváltott kezességek, lehívott garanciák;

- Az önkormányzati kötelező vagy önként vállalt feladatot ellátó költségvetési szervek és gazdasági társaságok által felvett hitelek;

- A kibocsátott kötvények vizsgálata, azok denominációja, futamideje, türelmi ideje és törlesztési kötelezettsége alapján;

- A belső eladósodottságra készített nagyvonalú becslés.

\section{Szubjektiv szempontok}

- A beruházások hitel-, kölcsöntörlesztését teljesíteni tudja-e az önkormányzat;

- $\mathrm{Az}$,off-budget” kötelezettségek jelentősek-e a hitelállományhoz képest.

\section{$\underline{\text { Likviditás }}$}

\section{Objektiv szempontok}

- Az önkormányzat betétállományának szerkezete, lejárata, kamatozása;

- A likvid hitelfelvétel mértéke és gyakorlata;

- Az önkormányzat értékpapír állományának vizsgálata, annak mértéke és az ezekböl bevonható bevételi források;

- Az önkormányzat pénztartalékának mértéke és annak változása.

\section{Szubjektiv szempontok}

- A szállítói tartozások mértéke és az átlagos fizetési határidők vizsgálata. Jellemzö-e az önkormányzatra a késleltetett számlázás;

- Az önkormányzat likviditás kezelési gyakorlata.

\section{Pénzügyi kapacitás}

\section{Objektiv szempontok}

- A bruttó megtakarítás vizsgálata, a működési költségvetés egyensúlyának elemzése;

- A nettó megtakarítás vizsgálata, és az adósságszolgálati terhek elemzése;

- A felvenni kívánt hitel/hitelek jövőbeni cash-flow szerkezetének elemzése, és annak megállapítása, hogy a hitel igényel-e jövőbeni pozitív nettó megtakarítást; 
- Meg kell vizsgálni, hogy az esetleges türelmi idők után mikor lép fel az elsö törlesztési kötelezettség. Van-e és ha igen mennyi a „rés” a jelenlegi bevételi struktúra és a jövöben keletkezö fizetési kötelezettségek között;

- A forráshiány vagy forrástöbblet megállapítása;

- PPP beruházások és az azok által keletkeztetett feltételes kötelezettségvállalások szerepe a pénzügyi kapacitás alakulásában.

Szubjektív szempontok

- Annak vizsgálata, hogy a devizában felvett hitelek és kibocsátott kötvények hatására keletkezö árfolyam veszteségek milyen mértékü kockázatot jelentenek az önkormányzat számára, és hogy ezen árfolyamkockázatok kivédésére milyen eszközöket használnak;

- A felhalmozási költségvetés egyensúlyának elemzése. A folyamatban lévő beruházások jelenbeli és jövőbeli támogatás igénye. A beruházások adott településszerkezetet is figyelembe vevő létjogosultsága. A beruházás finanszírozási szerkezete.

Bevételi kapacitás

Objektív szempontok

- Az önkormányzat bevételi szerkezetének vizsgálata;

- A bevétel hány százaléka tervezhető;

- A helyi adóbevételek mértéke és szerkezete;

- A helyi iparüzési adóból származó bevételek mértéke. A helyi iparüzési adót szolgáltató adóalanyok szerkezetének, megoszlásának vizsgálata. További adóalanyok betelepülésének valószínüsége;

- Helyi iparüzési adóból származó bevétel kiesése esetén adódó bevételi kapacitás mértékének vizsgálata.

Szubjektív szempontok

- A lakosság szerkezetének vizsgálata a személyi jövedelemadó potenciál tekintetében;

- A támogatásigénylés rendszerének vizsgálata, indokolatlan támogatás igénybevételek gyakorisága és azok szankcionálása.

\section{Feladatellátás}

Objektív szempontok

- A kötelezö és az önként vállalt feladatok müködési költségvetésben történő elkülönítése / elkülöníthetősége és ezek vizsgálata;

- A kötelező feladatok ellátásának forrásigénye és szerkezete. A támogatásokon felül a kötelező feladatok finanszírozásához igénybe vett saját források;

- Az önként vállalt feladatok ellátásának forrásigénye és szerkezete. Az önként vállalt feladatok finanszírozásának saját forrás igénye;

- Elöfordult-e már adósságrendezési eljárás a település életében? Ha igen, hogyan racionalizálta feladat ellátási kötelezettségeit? 
Tér és Társadalom 24. évf. 2010/1. 83-101. p.

Szubjektiv szempontok

- Szükség van-e a feladatok finanszírozása érdekében egyéb vállalkozási tevékenység folytatására;

- Az egyes közfeladatokat ellátó intézmények kapacitáskihasználtsága hogyan viszonyul a hasonló méretủ települések átlagához?

$\underline{\text { Településpolitika }{ }^{I 0}}$

Objektiv szempontok

- Az önkormányzat fiskális politikája, adókivetési és beszedési potenciálja, szándéka;

- A költségvetés tervezés hatékonyságának vizsgálata, terv-tény eltérések elemzése.

Szubjektív szempontok

- A vezetés szakmai felkészuiltsége;

- A folyamatban lévő beruházások indokoltsága;

- ÁSZ vizsgálati jelentések tartamának elemzése és a megállapítások betartásának vizsgálata;

- Vizsgálhatjuk a foglalkoztatottsági ráta alakulását, az óvodai, iskolai férőhelyek alakulását, a közmü- és közúthálózat kiépítettségét;

- Az adott önkormányzat regionális versenyképességének vizsgálata.

3) A tényezók kockázatát leginkább mérni képes pénzügyi mutatók meghatározása.

Könyvvizsgálók, bankok rendszerint az önkormányzatok számviteli beszámolójából (vagyonmérleg és a vállalati eredménykimutatás funkcióját betöltó pénzforgalmi jelentés és a pénzmaradvány kimutatás) indulnak ki, és a vállalati elemzésben megszokott pénzügyi mutatószámokat alkalmazzák. Ez a gyakorlatban több esetben is szakmailag értékelhetetlen eredményekre vezethet (Vigvári 2002a; 2002b; Kassó 2006; Gál 2009b).

A gazdasági elemzésben kiemelt szerepe van a pénzügyi és egyéb gazdasági arányszámok képzésének. Ezen arányszámok fontos jellemzöje:

- speciális intenzitási viszonyszámok;

- jellemzően (de nem kizárólagosan) számviteli kimutatásokra épülnek;

- képzésük közgazdasági-üzemgazdasági megfontolások alapján történik.

Ezek alkalmasak térbeli (különböző adottságú és nagyságrendű önkormányzatok) és időbeni (adott önkormányzat pénzügyi helyzetének) összehasonlítására, illetve a kettő kombinálására.

Bizonyos esetekben az összehasonlíthatóságot elősegítendő hasznosak lehetnek a fajlagos (például az egy före, egy ellátottra jutó) érték mutatók. A javasolt mutatók egy része a különbözö nyilvános kimutatásokból könnyen kiszámítható, de vannak olyanok is, amelyek csak a belsö információs rendszerekböl állapíthatók meg. Ezek összehasonlíthatóságának erős korlátjai vannak, de az adott önkormányzat 'önismeretét' javíthatják (Vigvári 2002a). 
Tér és Társadalom 24. évf. 2010/1. 83-101. p.

A javasolt mutatószám-rendszer felhasználásával olyan kombinált monitoring rendszerek kidolgozása lehetséges, amelyek akár a bankok, akár külső ellenőrző szervek által felhasználhatók. A mutatószám-rendszer kialakításánál törekedtünk öt olyan mutató meghatározására, melyek támpontot jelenthetnek az elemzések lefolytatásához. A szubjektív szempontok részletes vizsgálata alapján a fenti mutatókon kívül mélyebb elemzések végrehajtására is lehetöség nyílik. A modell tesztelése további mutatók megalkotására, és azok értelmezésére adhat lehetöséget! Az ilyen rendszerek alapját jelentő pénzügyi mutatószámok képzésénél - különösen az önkormányzatok esetében - figyelembe kell venni a szektor komplex szabályozási környezetét is.

4) A tényezók értékelése során kialakuló osztályzatok pontozási rendszerének kidolgozása. A tényezók súlyozása, a végsỏ osztályzatok definiálása.

$\mathrm{Az}$ eredeti CAMELS módszerben minden pénzintézet egy összetett minősítést kap, ami a pénzügyi helyzetét és müködését jellemző hat alapvető részből áll össze. Minden egyes tényező értékelése figyelembe veszi a pénzintézet méretét, gazdálkodási tapasztalatát, tevékenységeinek természetét, komplexitását és kockázati profilját. A tényezők értékelése és az összetett minősítés is egy 1-töl 5-ig terjedő skálán történik. Az 1-es a legjobb minősítés, ami a legmagasabb teljesítményt és a legjobb kockázatkezelési gyakorlatot jelöli, míg az 5-ös a legrosszabb minősítés, ami a leggyengébb teljesítményhez és a nem megfelelő kockázatkezelési gyakorlathoz kapcsolódik. Az összetett minösités szoros kapcsolatban áll a tényezök értékelésével, de nem azok számtani átlaga! Minden tényező minösítése kvalitatív és kvantitatív elemzésen alapul. Az összetett minősítés megállapításakor bármely olyan elemet figyelembe lehet venni, amely befolyást gyakorol a pénzintézet helyzetére, stabilitására.

Tekintettel arra, hogy az „Önkormányzati Risk Mapping” a fenti modell logikáját követi, ezért itt is egy 1-5 közötti skálán történik mind az egyes tényezök, mind az összesített minösités pontozása. Az eredmény skalár pontszám. A pontozásos módszer kialakításánál fontos szempont a tényezökre kapható pontok súlya az összes pontszámon belül (tényezö súly). Ugyancsak fontos kérdés, hogy az egyes tényezök osztályzatának kialakulásában a tényezö-értékelési szempontok vizsgálata során az egyes kvalitatív és kvantitatív szempontok és eredmények milyen súllyal vesznek részt. Vagyis, miként döl el az adott tényezó osztályzata, és ezek az osztályzatok milyen információt közvetítenek.

A fenti kérdések megválaszolása két idötávra bontva történhet meg. Rövid távon meghatározhatóak a tényezók súlyozásának kiindulási értékei az összesített minősítésen belül. Itt figyelembe kell venni azt, hogy az elemzés milyen céllal jön létre, vagyis banki hitelkockázat elemzés alátámasztására, független külső ellenôrzés céljából vagy a helyi önkormányzat döntéshozatali munkájához. Ennek megfelelóen elképzelhető megoldás lehet az is, hogy valamennyi tényező azonos súllyal vesz részt az összesített minősítésben.

Amennyiben a cél az egyes önkormányzat típusok (szegmensek) eltérő pénziigyi, müködési és területi sajátosságainak kiemelése, javasoljuk figyelembe venni az ÁSZ 
KUT 2008. nyarán végzett felmérésének eredményeit, mely az eltérö önkormányzattípusok különböző pénzügyi, müködési kockázatait azonosítja (Vigvári 2009). A hivatkozott elemzés alapján az egyes tényezők eltérő súlyozása adódik (2. táblázat), mely tükrözi az adott önkormányzattípus kockázati profilját és sajátosságait. Ennek megfelelően a modellszámításokhoz célszerủ meghatározni egy kiindulási értéket.

\section{TÁBLÁZAT}

A tényezók lehetséges súlyozása

(Possible Weighting of Risk Factors)

\begin{tabular}{|c|c|c|c|c|c|c|c|}
\hline $\begin{array}{l}\text { Önkormányzat } \\
\text { típus / Súlyok }\end{array}$ & Község & $\begin{array}{l}\text { Nagy- } \\
\text { község }\end{array}$ & Város & $\begin{array}{l}\text { Me- } \\
\text { gyei } \\
\text { jogú } \\
\text { város }\end{array}$ & Megye & $\begin{array}{c}\text { Fö- } \\
\text { városi } \\
\text { kerüle- } \\
\text { tek }\end{array}$ & $\begin{array}{l}\text { Fövá- } \\
\text { ros }\end{array}$ \\
\hline Eladósodottság & 0,1 & 0,1 & 0,25 & 0,25 & 0,2 & 0,166 & 0,25 \\
\hline Likviditás & 0,2 & 0,2 & 0,1 & 0,1 & 0,1 & 0,166 & 0,1 \\
\hline $\begin{array}{l}\text { Pénzügyi kapa- } \\
\text { citás }\end{array}$ & 0,1 & 0,1 & 0,25 & 0,25 & 0,2 & 0,166 & 0,25 \\
\hline $\begin{array}{l}\text { Bevételi kapa- } \\
\text { citás }\end{array}$ & 0,2 & 0,2 & 0,1 & 0,1 & 0,3 & 0,166 & 0,1 \\
\hline Feladatellátás & 0,2 & 0,2 & 0,1 & 0,1 & 0,1 & 0,166 & 0,1 \\
\hline Településpolitika & 0,2 & 0,2 & 0,2 & 0,2 & 0,1 & 0,166 & 0,2 \\
\hline Összesen & 1,0 & 1,0 & 1,0 & 1,0 & 1,0 & 1,0 & 1,0 \\
\hline
\end{tabular}

Forrás: Saját számítás.

A súlyok kialakításánál törekedni kell arra, hogy azok hosszabb idôtávon keresztuil is viszonylag stabilan alkalmazhatóak legyenek, mert ez segíti az idősorok elemzését is. A végső pontszámok pedig alkalmassá válhatnak a térbeli és időbeni összehasonlításra.

Ugyancsak rövid távú feladat az összesített osztályzatok definiálása (Gál 2009b), mely végső soron csoportokba rendezi az önkormányzatokat, müködésük kockázatosságának figyelembevételével.

Középtávú feladatnak értékeljük az objektiv és a szubjektív szempontok pontozási rendszerének és a hozzájuk rendelt osztályzatoknak a meghatározását. Segítséget jelenthetnek az egyes szegmensekben végzett nem reprezentatív mintavételen alapuló modellszámítások. Az egyes tényezők elemzése során itt szerzett tapasztalatok hozzá járulhatnak a pontozási rendszer kialakításához, finomításához. További kérdés, hogy a szubjektív pontok összesitett értékben, vagy tényezönkénti megbontásban kerüljenek figyelembe vételre ${ }^{11}$.

5) Modellszámítások végzése település típusonként (a benchmarkok létrehozása).

A különböző mutatószámok értékei önkormányzat típusok szerint rendkívül nagy szóródást mutathatnak. Ezt egyértelmủen jelzi az ÁSZ KUT pénzügyi kockázatokról készített tanulmánya is (Vigvári 2009). Mindezek alapján jól látható, hogy a pontozási rendszerhez használandó benchmark értékeket nem szektor átlagokból, 
Tér és Társadalom 24. évf. 2010/1. 83-101. p.

hanem az egyes önkormányzattípusok átlagaiból helyes levezetni. Az országos átlag és a szegmens átlagok eltéréseinek mindazonáltal fontos információs szerepük van.

Fontos megemlíteni, hogy az önkormányzatok közötti különbségek nem csak szegmens szinten vizsgálhatók. A modellszámítások és a létrehozandó adatbázis a regionális különbségek méréséhez is (Rechnitzer 1998) elöremutató segítséget nyújthat. A területi és regionális különbségek finanszírozási oldalról is (Lados 1998; Pitti 2005) fontos szerepet kapnak.

A négyes pontban leírtaknak megfelelöen az egyes tényezőket mérő mutatószámok konkrét értékeihez kapcsolódó pontértékek meghatározásához modellszámításokat kell végezni, mely kétségtelenül egy hosszabb munkafolyamatot vesz igénybe. E modellszámításokat megfelelően homogenizált múltbeli tényadatokra alapozva kell elvégezni. Egy ilyen munka hozadéka várhatóan nemcsak e rendszer kialakításának megalapozása, de egy sor további más összefüggés megismerése is lehet.

\section{6) A rendszer informatikai hátterének kialakitása.}

A megvalósítás középtávú tervei közé tartozik a modellszámításokon alapuló, helyesen súlyozott rendszer informatikai hátterének megteremtése, annak programozhatóvá tétele.

\section{Egy elvégzett modelltesztelés tapasztalatai}

A fentiekben bemutatott modell gyakorlati tesztelése a mutatószámok értelmezhetősége, a tényezőértékelési szempontok relevanciája és a modell egyéb szempontok szerinti továbbfejlesztése tekintetében is hasznos. Az Eger Megyei Jogú Város önkormányzatának 2005-2007 közötti gazdálkodását elemző esettanulmány (Gál 2009b) egy ilyen modelltesztelést végzett el. Az elemzés tapasztalatai felhívják a figyelmet arra, hogy a modell a megfelelő modellszámítások elvégzését követően képessé válhat az önkormányzati gazdálkodás során érzékelhető területi különbségek megragadására is.

A tényezők közül a bevételi kapacitás vizsgálatát emeljük ki (3. táblázat), melynek során speciális mutatószámok lehetnek alkalmasak a bevételi kapacitás mérésére.

A bevételi kapacitást méró mutatókat vizsgálva, mind a saját bevételek, mind pedig a helyi adóbevételek esetében növekvő tendencia figyelhető meg. A számok önmagukban való értelmezése még nem helyezi el bevételi kapacitás szempontjából az önkormányzatot. Ehhez van szükség szektor szintü adatokra is. A 3. ábrán bemutatott adatok alapján megállapítható, hogy a megyei jogú városok viszonylatában az egy lakosra jutó adóbevételek tekintetében Eger 2008-ban a 11. helyet foglalta el. Ez alátámasztja a bevételi kapacitás kielégítő nagyságát, egyben felhívja a figyelmet arra, hogy a mutató tekintetében jelentös regionális eltérések tapasztalhatók.

$\mathrm{Az}$ önkormányzat legjelentösebb bevételi tételei a saját bevételek és a központi költségvetési támogatások. Ugyancsak markáns elemet képviselnek az átengedett adok. Mind a központi költségvetési támogatások, mind az átengedett központi adók eseté- 
Tér és Társadalom 24. évf. 2010/1. 83-101. p.

ben érzékelhető Eger esetében is az általános tendencia, ami a támogatások csökkenésének irányába hat. Részben a támogatási rendszer folyamatos változtatása miatt, részben ezen összegek reálértékének csökkenése miatt.

\section{TÁBLÁZAT}

Eger bevételi kapacitását mérö lehetséges mutatók

(Possible Indexes of Income Capacity)

\begin{tabular}{|c|c|c|c|}
\hline Megnevezés & 2005 & 2006 & 2007 \\
\hline Illetékek $(\mathrm{eFt})$ & 405138 & 408588 & 354455 \\
\hline Helyi adók (eFt) & 2423310 & 2543314 & 2892643 \\
\hline ezen belül helyi iparüzési adó (eFt) & 1986114 & 1772513 & 2469510 \\
\hline Egyéb saját bevételek $(\mathrm{eFt})$ & 2866276 & 3459866 & 3209869 \\
\hline Saját bevételek összesen (eFt) & 5694724 & 6411768 & 6456967 \\
\hline Összes bevétel (eFt) & 16848140 & 18508717 & 20197370 \\
\hline Egy före jutó saját bevétel (eFt/fö) & 101 & 115 & 116 \\
\hline Egy före jutó helyi adóbevétel (eFt/fö) & 43 & 45 & 52 \\
\hline $\begin{array}{l}\text { Egy före jutó helyi adóbevétel IPA nélkül } \\
(\text { eFt/fö) }\end{array}$ & 8 & 14 & 8 \\
\hline $\begin{array}{l}\text { Egy fớre jutó saját bevétel lPA nélkül } \\
(\text { eFt/fö) }\end{array}$ & 66 & 83 & 71 \\
\hline Helyi adók / saját bevétel (\%) & $42,5 \%$ & $39,6 \%$ & $44,8 \%$ \\
\hline
\end{tabular}

Forrás: Költségvetési mérleg adatok alapján saját számítás.

3. ÁBRA

Egy lakosra jutó önkormányzati adóbevételek nagysága, 2008 (Mrd Ft)

(Self-governments Tax Revenues per an Inhabitant, 2008 [Mrd HUF])

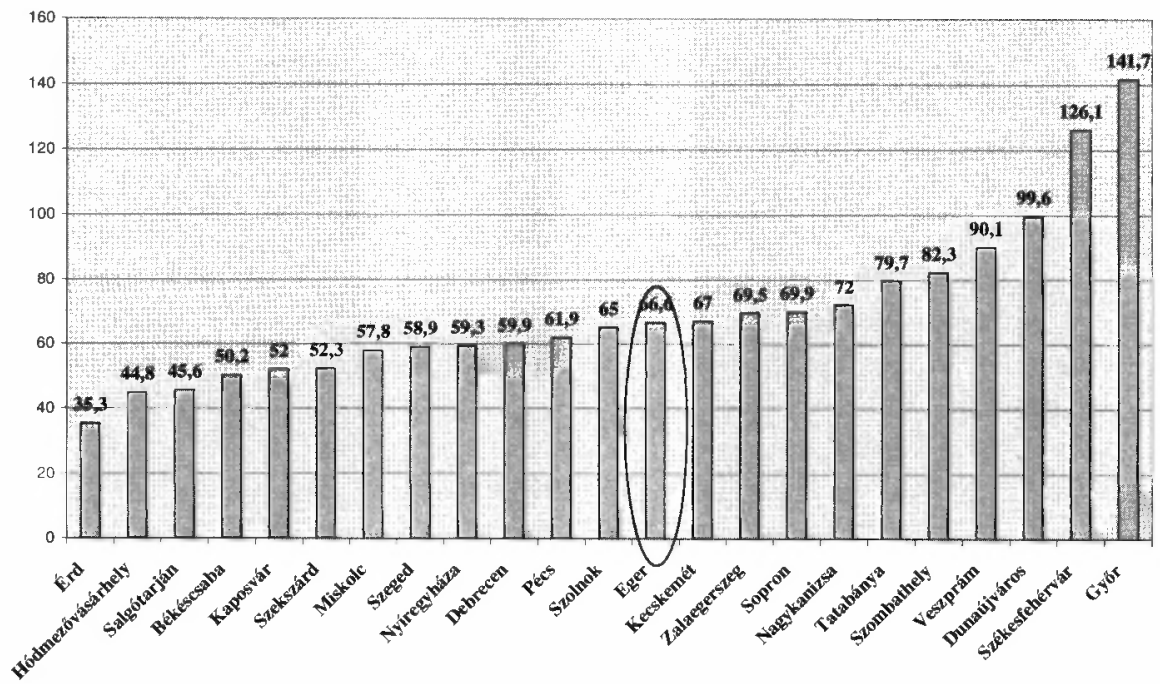

Forrás: Eger város önkormányzata adatai alapján saját szerkesztés. 
Eger sajátosan kedvezö helyzetben van a bevételi szerkezetét illetően, hiszen a saját bevételek magas szinten tartása lehetővé teszi a költségvetéstől való függőség lazítását. A költségvetés tervezésének nagyobb szabadságot ad, illetve a beruházások tervezése és megvalósítása során is kedvezỏ helyzetbe kerülnek azok az önkormányzatok, amelyek magas saját bevételi potenciállal rendelkeznek.

A saját bevételek tekintetében a legjelentösebb súllyal a helyi adók szerepeltek a bevételi szerkezetben, 2005-ben 42,5\%-os, 2006-ban 40\%-os, 2007-ben 44,8\%-os részaránnyal. A megyei jogú városok rangsorát tekintve a helyi adóbevételek esetében Eger város a 2008. évi adatokat tekintve (4. ábra) a középmezőnyben helyezkedik el.

\section{4. ÁBRA}

Helyi adóbevételek, 2008 (Mrd Ft)

(Local Taxes, 2008 [Mrd HUF])

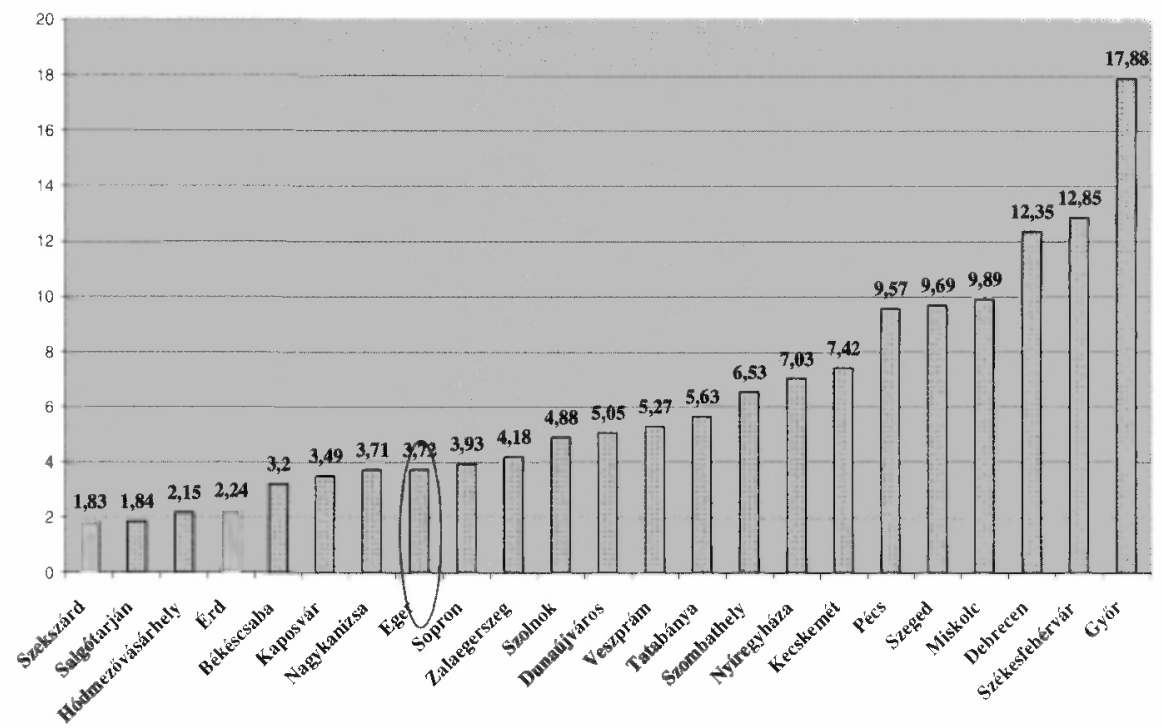

Forrás: Eger város önkormányzata adatai alapján saját szerkesztés.

\section{Összegzés}

A pénzügyi kockázatok már napjainkban is jelen vannak az önkormányzati rendszerben. Annak sajátosságai miatt együtt él vele valamennyi önkormányzat, ám azok kialakulása és jövőbeni felépülése nem kizárólag az önkormányzatok felelőssége. Míg a községek, nagyközségek elsősorban likviditási gondokkal küzdenek, addig a darabszámát tekintve kísebb csoport (megyék, megyei jogú városok, városok) eladósodottsága miatt hordoz komoly makrogazdasági kockázatot.

Az önkormányzatok az üzleti szektorban alkalmazottaktól eltéró számviteli elveket tudhatnak magukénak. Ez indokolja, hogy gazdálkodásuk elemzését és értékelését is 
eltérỏ elvekre alapozzuk felhasználva az elemzési módszerek interdiszciplináris jellegét. Egy ilyen módszer megalkotására tesz javaslatot ez a tanulmány.

A tanulmányban bemutatott rendszer hozzájárulhat az önkormányzati szektor átláthatóságának javításához is. Folyamatosan bővül azoknak a szakmai észrevételeknek a köre, melyek szorgalmazzák a független pénzügyi ellenőrzés fejlesztését, a transzparencia biztosítása céljából. „Idöszerü a helyi önkormányzatok gazdálkodásának komplex (átfogó) megítélésére szolgáló eljárások kifejlesztése és a számvevőszéki ellenörzésben való - a településeket segítő szándékú - alkalmazása. A független külső ellenörző szervnek kvantifikált, egyszerủen áttekinthető, egymással összehasonlítható, 'felhasználóbarát' minősítéseket, értékeléseket kellene készítenie, amiket célszerü lenne az interneten nyilvánosságra hozni." (Nyikos 2009, 154)

A téma komplexitása, valamint az önkormányzati szektor sajátos összetétele miatt a vázolt modell nem zárt rendszert kínál. Egy olyan modell ötletét tárja az olvasó elé, melynek sorozatos tesztelésével és programozásával alkalmassá válhat az önkormányzati hitelezésben aktív bankok hiteldöntéseinek megalapozására, segítséget nyújthat az Állami Számvevőszék ellenőrzési munkájának racionalizálásában, valamint a helyi önkormányzatok gazdálkodásában egyaránt.

\section{Jegyzetek}

${ }^{1}$ A pénzügyi architektúráról ld. Vigvári (2005). Az önkormányzatok pénzügyi architektúrája magában foglalja:

a) az önkormányzatok adóztatási jogosítványait;

b) a központi adók átengedésének, megosztásának szabályait, annak tárgyát;

c) a központi transzferek, támogatások szabályozását, tervezhetőségét, kiszámíthatóságát;

d) az önkormányzatok pénz és tőkepiaci kapcsolatait;

e) a költségvetési korlát keménységét;

f) az információs rendszer felépítését, müködési szabályait.

${ }^{2}$ Az arányosság kérdése komoly vita tárgyát képezi szakmai körökben.

${ }^{3}$ Az instrumentumok csoportosítását ld. Györffi-Vigvári-Zsugyel (2009, 107-109).

${ }^{4}$ Többváltozós korreláció- és regresszió számítás, faktoranalízis, diszkriminancia-analízis, klaszter analizis, MDS (MultiDimensional Scaling) stb. (Lengyel 1999).

${ }^{5}$ A rendszer csúcsmutatója a tökemegtérülés, a ROI (Return on Investment), a nyereség és a befektetett tő́ke hányadosa, melyet részmutatókra bonthatunk fel.

${ }^{6}$ Pénzügyi és nem pénzügyi jellegü mutatók kombinációját tartalmazza a hosszú távú versenyképesség és a hagyományos pénzügyi mutatók összekapcsolásával. A BSC mutatók képzése négy nézópont szerint történik, melyek a pénzügyi, vevöi, müködési folyamatok és emberi eröforrások, valamint a fejlödési képességek nézöpontja.

${ }^{7}$ Ezt az ábrázolási módot mutatja be Vigvári (2002b) munkája.

${ }^{8}$ A kockázatok nevesítéséhez felhasználtuk az ÁSZ KUT pénzügyi kockázatokról szóló felmérését (Vigvári 2009).

9 Az önkormányzati kockázatok közötti ok-okozati kapcsolatot levezette Vigvári (2002b) cikke. Az alábbi feldolgozás a fent hivatkozott tanulmány aktualizálására tesz kísérletet, a szükséges mértékủ átdolgozással.

${ }^{10}$ A településpolitika önmagában a legszubjektívebb tényező. Ennek a tényezönek a kapcsán is törekedni kell azonban objektíven mérhető mutatók szerkesztésére. 
Gál Erzsébet : Az „Önkormányzati Risk Mapping”

avagy a "CAMELS típusú" elemzésen alapuló önkormányzati rating és monitoring rendszer. Tér és Társadalom 24. évf. 2010/1. 83-101. p.

${ }^{11}$ A hagyományos rating típusú értékeléseknél a szubjektív szempontok figyelembe vétele összesítetten történik. Alapvetó követelmény, hogy a szubjektív szempontokra adott pontok száma ne haladja meg az objektív pontok számát.

\section{Irodalom}

ÁSZ FEMI (2007) Közpénzügyek szabályozásának tézisei. ÁSZ FEMI, Budapest.

Economic Research (1999) FRBSF Economic Letter Number 99-19. Economic Research.

Gál E. (2009a) Bankok, bankïgyletek. Egyetemi jegyzet. Miskolci Egyetem Kiadó, Miskolc.

Gál E. (2009b) Az önkormányzatok adós és követelésminösitésének elméleti és gyakorlati problémái. Phd értekezés tervezet. Miskolc.

Győrffi D.-Vigvári A.-Zsugyel J. (szerk.) (2009) A közpénzügyek nagy kézikönyve. Complex Kft., Budapest.

Hegedűs, J. (2004) Off-budget Revenues and Expenditures: A Challenge to Subnational Financies. Kopányi, M.-Wetzel, D.-Daher, S.E. (eds.) Intergovernmental Finance in Hungary. A Decade of Experience 1990-2000. World Bank, OSI Budapest.

Hegedús J.-Tönkö A. (2007) Az önkormányzati gazdasági társaságok szerepe a helyi önkormányzatok vagyongazdálkodásában: a feltételes kötelezettségvállalás (,contingent liability”) problémája. Vigvári A. (szerk.) A családi ezüst. Tanulmányok az önkormányzati vagyongazdálkodás témaköréböl. Közigazgatási olvasmányok. COMPLEX Kiadó, Budapest.

Homolya D.-Szigel G. (2008) Önkormányzati hitelezés - kockázatok és banki viselkedés. - MNB Szemle. Szeptember. 20-29. o.

Kaplan, R.S.-Norton, D.P. (1998) „Balanced Scorecard kiegyensúlyozott stratégiai mutatószámrendszer - Egy eszköz, ami mozgásba hozza a stratégiát". KJK, Budapest.

Kassó Zs. (2006) Miért van szuikség az államháztartås pénzügyi beszámolórendszerének megváltoztatására? - Vigvári A. (szerk.) Decentralizáció, transzparencia, elszámoltathatóság. Magyar Közigazgatási Intézet, Budapest.

Kornai J.-Maskin, E.- Roland, G. (2004a) Puha költségvetési korlát L - Közgazdasági Szemle. Júliusaugusztus. 608-624. o.

Kornai J.-Maskin, E.- Roland, G. (2004b) Puha költségvetési korlát II. - Közgazdasági Szemle. Szeptember. 777-809. o.

Kotler P. (1991) Marketing menedzsment. Elemzés, tervezés, végrehajtás és ellenörzés. Müszaki könyvkiadó, Budapest.

Lados M. (1998) Az önkormányzati finanszírozás lehetséges jövőbeli irányai. - Tér és Társadalom. 1-2. 59-86. o.

Lengyel I. (1999) Mérni a mérhetetlent? A megyei jogú városok vizsgálata többdimenziós skálázással. Tér és Társadalom. 1-2. 53-73. o.

Lóránt Z. (2009) A gazdasági válság hatása az államháztartásra, különös tekintettel az önkormányzatokra. A BGF Tudományos konferenciáján, a Tudomány Napján elhangzott elóadás. 2009. november 13. Budapest.

Nyikos L. (2009) A helyi önkormányzatok pénzügyi ellenörzésének jogi és szakmai szabályozása néhány EU-tagországban. - Pénzügyi Szemle. 1. 152-171. o.

Pitti Z. (2005) Az önkormånyzatok pénzügyi finanszírozásának modernizációja. - Vigvári A. (szerk.) Fêlúton. Tanulmányok a helyi önkormányzatok finanszirozási rendszerének továbbfejlesztési lehetöségeiról. BMA IDEA, Budapest.

Rechnitzer J. (1998) A teruileti stratégiák. Dialóg Campus Kiadó, Budapest-Pécs.

Varga I. (2007) Az üzemgazdasági szemléletü vagyongazdálkodás megteremtésének helyzete. - Vigvári A. (szerk.) A családi ezüst. Tanulmányok az önkormányzati vagyongazdálkodás témaköréból. Közigazgatåsi olvasmányok. COMPLEX Kiadó, Budapest.

Vigvári A. (2002a) Az önkormányzati rendszerre alkalmazható CAMELS típusú monitoring rendszer koncepciója. Vitaanyag és megvalósíthatósági tanulmány. Készült az ÁSZ FEMI részére.

Vigvári A. (2002b) Kockázatok és mérési lehetöségeik az önkormányzati gazdálkodásban. Kézirat. ÁSZ FEMI, Budapest.

Vigvári A. (2005) Közpénzügyeink. KJK Kerszöv, Budapest.

Vigvări A. (2008) Szubszidiaritás nélküli decentralizáció. Néhány adalék az önkormányzatiság magyar modelljének korszerüsítéséhez. - Tér és Társadalom. 1. 141-167. o.

Vigvári A. (2009) Pénzzïgyi kockázatok az önkormányzati rendszerben. ÁSZ KUT tanulmány, Budapest. Zupkó G. (2002) Közigazgatási reformirányzatok az ezredfordulón. Századvég Kiadó, Budapest. 